\title{
The Potential Opportunities in International Portfolio Diversification
}

\author{
Dr. Nesma Ahmed Heshmat \\ Associate Professor, Faculty of Commerce \\ Assiut University \\ Arab Republic of Egypt
}

\begin{abstract}
This study aims to investigate potential opportunities in international portfolio diversification. The study searches the opportunities for Egyptian investors in the Middle East and North Africa (MENA), European, Asian and United States stock markets. The study investigates the relationship of the Egyptian's stock market equity indices with world markets through examining the co-integrating behaviour, Granger causality tests, Variance Decompositions and Impulse Responses. A domestic portfolio has been composed to be used as a benchmark in comparing the benefit of international portfolio diversification using the mean-variance Portfolio Optimization (PO) approach. The results reveal that however the Egyptian market is integrated to the world market, there are still some gains could be achieved from international diversification.
\end{abstract}

Keywords: Egyptian stock markets; portfolio diversification; Johansen co-integration test; causality; impulse response; variance decomposition.

\section{Introduction}

The benefit of international equity diversification has been studied extensively from early financial literature. Solnik (1974) and Watson (1978) refer to the benefits of international diversification and how that spreading investment across several independent countries may significantly improve portfolio performance to a level which cannot be attained within a domestic portfolio as a result of the low correlation among international assets compared to domestic assets. The low correlation among international assets led to substantial gain from diversification (De Fusco et al., 1996 ; Cheol et al., 2008).

In other words, the benefits from international diversification depend on the relationships among stock markets and the degree of their independence. During last decades, this topic attracted considerable attention to measure the international market integration and the benefit of international diversification.

Longin and Solnik (1995) argue that the gain from international diversification decreases as the level of markets integration increases. Many literatures argue that the global stock markets become more integrated. Therefore, recently the benefit from integration fad up and no reason for diversified internationally. For example, De Jong and De Roon (2005) found that equity markets of emerging countries have become more integrated with international equity markets. Kim et al. (2005) found similar results in the Euro zone as they argued that the level of market integration increased in the post-Euro era. Bley (2007) find that MENA stock markets have become more integrated overtime. Similar results were found by (Carrier et al. :2007; Kazi et al. :2013).

* This article was submitted in November 2017, and accepted for publishing in January 2018. 
On other hand, some studies have indicated that MENA stock markets are segmented from the world markets, and not integrated with each other (e.g. Al-Kulaib, et al., 2009; Girard, et al., 2003)

Li et al. (2003) argue that although the global markets have become more integrated, it does not negate the benefits of international diversification in emerging markets.

Thus the study tries to answer the following questions

- Is the Egyptian market integrated or segmented with the global market?

- Is there any benefit that the Egyptian investor can gain from diversifying internationally?

\section{The Study Objective}

The objective of the study is to investigate the relationship of the Egyptian's stock market equity indices with world markets through examining the co-integrating behaviour, Granger causality tests, Variance Decompositions and Impulse Responses. A domestic portfolio has been composed as benchmarks to compare the benefit of international portfolio diversification using the mean-variance portfolio optimization (PO) approach. The study investigates potential opportunities in international portfolio diversification for Egyptian ' investors in the Middle East and North Africa (MENA), European, Asian and the United States equity markets. The study includes sixteen markets: ten from MENA region (Jordan- Tunisia - Morocco and seven Gulf Cooperation Council (GCC)), three European (France - Germany - UK), two Asian (ChinaJapan) and United States.

\section{Importance of the Study}

The main contributions of this study are in the areas of international diversification from Egyptian investors point of view. While there are some literatures studied the diversification in the MENA region. All of these studies investigate the benefits that the developed markets can gain from adding emerging markets to their portfolio, this is the first study which examines the benefits for the Egyptian investors in particular. The study adds and supports the existing literature on the benefits of diversifying internationally, and should have significant implications for investors (individual or institutions) and for fund managers who want to diversify internationally.

\section{Literature Review}

Different countries have different economic conditions. They differ in their fiscal and monetary policy cycles, and they differ of return-generating mechanisms. It is rare to find a market that perfectly correlated with other markets or regions. This is why international diversification makes sense. Therefore, investor could gain from holding a portfolio that is diversified across a number of countries or regions (Gregg, 2012).

Complete stock markets integration would mean that stocks in the studied markets are exposed to the same risk factors and thus the risk premium on each factor is the same in all markets. Co-integration means that, however many developments can cause permanent changes in each of the individual series, there are some long-run equilibrium relations tying the individual series together. If stock prices are co-integrated, prices in different markets cannot move far away from each other, and there is some adjustment mechanism 
bringing the prices back towards the long-run relationship. On other hand, no co-integration means that stock markets have no long-run link and stock prices in different markets can diverge without bound. The co-movements of stock prices and co-integration reflect the integration of stock markets. In other words, one would expect stock prices to be co-integrated if stock markets are integrated (Ahlgren and Antell, 2002). Once markets become fully integrated, they are treated as a single market. Therefore, markets are completely integrated when assets with the same risk have the same expected returns, irrespective of the market they have been sold in. The hypothesis of integration among countries means the situation when all barriers (capital controls and other institutional barriers) to the internal trade liberalisation among those countries are eliminated. The elimination of the barriers will mean no more arbitrage among those countries and if there were price differences, then arbitrage would occur until the differences disappeared. Assets with the same risk will have the same expected returns. The opposite situation is segmentation, where some countries have barriers in the capital markets such as the movement of finance/funds between one country and capital controls. This is because such restrictions induce market segmentation. In practice, the relationships between most markets are located somewhere between complete integration and complete segmentation. In other words, when integration is not full and complete, the state of affairs might very well be such that it shows neither integration nor segmentation, and then we can speak about the degree of integration. In fact, there is a difficulty in determining the degrees of segmentation or of integration, since segmentation and integration are on a continuum - that is, a partially integrated market could be one with a degree of segmentation. It can also be that some parts of the market are integrated (between countries) and others not.

Co-integration estimation techniques developed by Engle and Granger (1987) and Johansen (1988) widely applied by scholars of finance. Recently, a number of papers have used co-integration to study the long-run co-movements of international stock prices and stock market integration. Numerous of these recent studies have explored the co-integration relations in the developed stock markets. Phengpis and Apilado (2003) found that the stock market price index for the major five EMU countries were co-integrated over the period from January 1979 until June 2002 and the co-integration relations became stronger over the passage of time. Bessler\& Yang (2003) used co-integration test and suggested that US has a consistent long run effects on Australia, France, Germany, UK, Switzerland, Japan, Hong Kong, and Canada.

A number of financial literatures have focused on emerging stock markets in the MENA region. Darrat et al. (2000) investigated degree of integration among Morocco, Jordan and Egypt for the period from October 1996 through August 1999 and found that the Egyptian market has a dominant force in the region, they also found that the three markets are segmented internationally, but appear highly integrated within the region which implies that these markets offer potential gains from diversification to international investors.

Neaime (2002) found weak integration among Egypt, Jordan, Morocco and Turkey during the nineties while the integration between these markets and US, UK and France is strong.

Parsva and Lean (2011) investigated six MENA countries (Egypt, Jordan, Saudi Arabia, Oman, Kuwait, and Iran) before and during the global financial crisis. They found that as the bidirectional causal relation is found for all countries except Iran, the interactions between the markets have increased during the crisis.

On other hand, some studies have indicated that MENA stock markets are segmented from the world markets, and not integrated with each other (e.g. Al-Kulaib, et al., 2009; Girard, et al., 2003). 
Al-Kulaib et al. (2009) investigated the linkage between stock market returns for twelve different countries' indices in the MENA region. These countries include: Egypt, Bahrain, Jordan, Kuwait, Oman, Morocco, Lebanon, Qatar, Saudi Arabia, UAE, Tunisia and Turkey. From January 3, 1999 to December 31, 2004. They found that the Egyptian stock market is auto-correlated and it does not influenced by lagged returns of Morocco or Tunisia markets. They also deduced that no causality or return spillover from one country to another in the North Africa region. The results for the GCC region show that there is more interaction and linkage in the GCC region than North Africa and Levant regions.

Yu and Hassan (2008) reported long-run equilibrium relation between the four markets (Egypt, Morocco, Jordan, and Turkey) and US stock markets. They also deduced that the interdependence among MENA stock markets is growing but still weak.

Guesmi and Teulon (2014) investigated the evolution of the process of integration in Middle East equity markets. Their estimated of the integration indices suggests that there are wide ranges in the degree of integration. Egypt has the highest market integration over the whole sample and Jordan is the most segmented.

\section{Data and Methodology}

The data used in this study were weekly closing stock market index from $27^{\text {th }}$ of March 2011 to Jun 2016. This is to exclude the effect of the $25^{\text {th }}$ of January 2011 in the Egyptian stock market. The Egyptian stock exchange closed at the end of trading on the $27^{\text {th }}$ January after the benchmark EGX 30 Index dropped $16 \%$. The drop of that week was from 6723.2 points on $24^{\text {th }}$ of January to 5646.5 points on 27 th of January. The exchange reopened on Wednesday $23^{\text {rd }}$ of March after closing for about eight weeks.

Ezzat (2012) found that during the revolution period, all market indices exhibited high standard deviations - implying high volatility of stock returns.

The data include nine MENA countries, six of them are Gulf Cooperation Council (GCC), three other Middle East (Jordan- Tunisia - Morocco), three European Markets (France - Germany - UK), two Asian markets (China- Japan) and United States. The sample consists of 4352 observations (272 weeks x 16 markets $=4352)$

\section{The following share price indices were used:}

- EGX30 for Egypt

- Gulf Cooperation Council (GCC)

- Bahrain All Share (BAX) for Bahrain.

- DFM General (DFMGI) for Dubai.

- $\operatorname{MSM} 30(\mathrm{MSI})$ for Oman.

\section{Other Middle East Markets}

- Amman SE General (AMGNRLX) for Jordan.

- Moroccan All Shares (MASI) for Casablanca.
- S\&P 500 (SPX)for U.S.

- Tadawul All Share (TASI) for Saudi Arabia.

- QE General (QSI) for Qatar.

- ADX General (ADI) for Abu Dhabi

- (KWSE) Main Market for Kuwait. 


\section{European Markets}

- $\quad$ CAC 40 (FCHI) for France

- DAX (GDAXI) for Germany

- $\quad$ FTSE 100 (FTSE) for UK.

\section{Asian Pacific}

- Nikkei 225 (N225) for Japan.

- FTSE China A50 (FTXIN9) for China.

The data of the price index collected from (Investing.com).

\section{1- The Unit Root Test}

The data of the study are time series. Therefore, there is a possibility that the data series is a non-stationary series. A non-stationary data series is defined as one which has a different mean at different point in time and its variance increases with the sample size. Using the Ordinary Least Square (OLS) with non-stationary data can lead to spurious regression. This implies that there is a problem of falsely concluding that a relationship exists between two non-stationary data series, when such relationship does not exist. Therefore, testing for the stationary or non-stationary of the data is important. Thus the Augmented Dickey- Fuller (ADF) and Phillip Perron (1988) unit root tests are used. The following ADF model was employed.

$$
\Delta y_{t}=\mu+\gamma_{t}+\left(\rho_{a}-1\right) y_{t-1}+\Sigma p_{j=1} \psi_{j} \Delta y_{t} j+\mu_{t}
$$

\section{2- Co-integration Test}

Co-integration estimation techniques developed by Engle and Granger (1987) and Johansen (1988) widely applied by scholars of finance. Recently, numbers of papers have used co-integration to study the long-run co-movements of international stock prices and stock market integration.

Engle and Granger (1987) suggested the use of the ADF tests to estimate the long-run relationship in single equations, for example, estimating the long-run relationship between $x$ and $y$ where:

$$
x=a+b y
$$

Assuming that the two series are both $\mathrm{I}(\mathrm{d})^{1}$ according to the definition of co-integration the two series would be co-integrated of order $\mathrm{Cl}(\mathrm{d}, \mathrm{b})$ if there exists a parameter (b) such that a linear combination of the two series is I(d-b). This implies that we can estimate equation (2) by using the OLS. The null hypothesis of no co-integration will test whether the residuals are I (1) versus the alternative that they are I (0).

With multivariate systems when there is a possibility of several co-integration relationships among variables, another approach called the Johansen procedure (Johansen, 1988) is used.

The simplest form of the Johansen test for co-integration is:

$$
\mathrm{Z}_{\mathrm{t}}=\mathrm{A}_{1} \mathrm{Z}_{\mathrm{t}-1}+\ldots . .+\mathrm{A}_{\mathrm{k}} \mathrm{Z}_{\mathrm{tk}}+\varepsilon_{\mathrm{t}}
$$

1 The series yt is said to be integrated of order one, denoted I (1), because taking a first difference produces a stationary process. A non-stationary series is integrated of order $\mathrm{d}$, denoted $\mathrm{I}(\mathrm{d})$, if it become a stationary after being differenced $d$ times. 
where $Z_{t}$ is a vector of $p^{* 1}$ potentially endogenous variables and could include up to $k$ - lags. $\varepsilon_{t}$ is an independent and identically distributed (i.i.d.). This model can be rewritten in the Vector Error Correction Model (VECM) form:

$$
\Delta \mathrm{Z}_{\mathrm{t}}=\Pi \mathrm{Z}_{\mathrm{t}-\mathrm{k}}+\Gamma_{1} \Delta \mathrm{Z}_{\mathrm{t}-1}+\ldots . .+\Gamma_{\mathrm{k}-1} \Delta \mathrm{Z}_{\mathrm{t}-\mathrm{k}+1}+\varepsilon_{\mathrm{t}}
$$

where $\Delta=(1-\mathrm{L})$ and $\mathrm{L}$ is the lag operator. The reason for doing this is that now all the long run information in the $\mathrm{Z}_{\mathrm{t}}$ process is summarized by the 'long-run impact matrix', II, and it is the rank of this matrix that determines the number of co-integrating vectors. The matrix $\Pi$ is decomposed as $\Pi=\alpha \beta$, where $\alpha$ and $\beta$ are both $p^{*} r$ matrices. Rank can range from zero to the number of variables in $(p)$ minus one. Thus, a system of two variables may have at most one co-integrating vector. The rank of $\Pi$ is equal to the number of its statistically significant characteristic roots. If $r=0$ ( $r=$ the number of co-integrating vectors $)$, the variables in $Z_{t}$ are not co-integrated and the traditional VAR may be estimated. If $r=1$, the co-integrating vector is unique. The number of co-integrating vectors can range up to $p-1$.

\section{3- Granger Causality test}

The study uses Granger Causality test to determine whether one market is useful in forecasting another. The Granger (1969) approach to the question of whether $X$ causes $Y$ is to see how much of the current can be explained by past values of and then to see whether adding lagged values can improve the explanation. Or, the ability to predict the future values of $Y$ using the histories of both $X$ and $Y$ better than it can be predicted using the history of $Y$ alone. When time series $X$ Granger-causes time series $Y$, the patterns in $X$ are approximately repeated in $Y$ after some time lag. Thus, past values of $X$ can be used for the prediction of future values of $\mathrm{Y}$. The bivariate regressions as the following equations:

$$
\begin{aligned}
& y_{t}=\alpha_{0}+\alpha_{1} y_{t-1}+\ldots .+\alpha_{i} y_{t-1}+\beta_{1} x_{t-1}+\ldots . .+\beta_{i} x_{t-1}+\varepsilon_{t} . \\
& x_{t}=\alpha_{0}+\alpha_{1} x_{t-1}+\ldots . .+\alpha_{i} x_{t-1}+\beta_{1} y_{t-1}+\ldots . .+\beta_{i} y_{t-1}+\mu_{t} .
\end{aligned}
$$

\section{4- Variance Decompositions and Impulse Responses}

The study uses the variance decompositions and impulse responses to examine the relationship between the Egyptian market and international markets over time.

The variance decomposition allows the relative importance of each market in generating unexpected variations in the price of its own equity market and the other markets to be measured over different time horizons (Dekker et al., 2001). The variance decomposition breakdowns the variance to show the proportion of the movements in the dependent variables that are due to their 'own' shocks, versus shocks to the other variables.

The impulse response function measures the speed of transmission of the pricing shocks information and its persistence from one market to another. In other words, it measures the time profile of the effect of shocks on the future states of a dynamic system (Koop et al., 1996). 


\section{5- Portfolio Optimization}

The study uses the Mean-Variance (MV) portfolio optimization (PO) model introduced by Markowitz (1952). Markowitz argues that by spreading the investment across a wide array of stocks, the investors could benefit from diversification. He shows that the return of a portfolio is weighted average of the component stocks`return. The formulation of Markowitz's mean-variance analysis (1952) is:

\section{Maximize $\mathrm{E}\left(\mathrm{R}_{\mathrm{p}}\right)=\Sigma_{\mathrm{i}=1} \mathrm{~W}_{\mathrm{i}} \mathrm{R}_{\mathrm{i}}$ subject to}

where $R_{p}$ is the return on the portfolio, $R_{i}$ is the return on stock $i$, and Wi is the weight attached to (proportion of total investment in) stock $i$. its variance $s_{p}{ }^{2}$ and $s_{i j}$ is the covariance.

The portfolio risk determined by two characteristics: the weighted risk of individual assets (standard deviations) and the weighted relationships between the assets (covariance). Efficient Frontier (or portfolio frontier) represents set of optimal portfolios that offers the highest expected return for a defined level of standard deviations or the lowest standard deviations for a given level of expected return. It is usually exhibited as a curve on a graph comparing risk against the expected return of a portfolio to describe the relationship between expected portfolio returns and the riskiness or volatility of the portfolio.

\section{Empirical Analysis}

\section{Descriptive Statistics}

Some summary statistics for the stock price index series are given in Table (1). Skewness and kurtosis results indicate that the share prices for all the countries included in the sample do not follow the normal distribution as the skewness is far away from zero. This indicates that the distributions of the data do not look the same to the left and right of the centre point. The skewness was negative for five markets (Abu Dhabi, Jordan, U.K, France, Germany, and U.S) which imply that the distribution has a long left tail. The rest of markets with positive skewness for means as the distribution has a long right tail. The kurtosis for a standard normal distribution is three. China kurtosis is 4.265 that exceed 3 as its distribution is peaked (leptokurtic) relative to the normal. The rest of markets the kurtosis is less than 3 , and the distribution is flat (platykurtic) relative to the normal.

Table (1)

Descriptive Statistics for Stock Price Index.

\begin{tabular}{|lllllll|}
\hline & Mean & Std. dev. & Skewness & Kurtosis & Jarque-Bera & Prob. \\
\hline $\begin{array}{llllll}\text { Egypt } \\
\text { GCC Markets }\end{array}$ & 6547.295 & 1709.304 & 0.341732 & 1.85824 & 20.36329 & 0.0000 \\
\cline { 1 - 3 } & & & & & & \\
Saudi & 7785.882 & 829.8371 & 0.457 & 2.071 & 18.971 & 0.0001 \\
Qatar & 10169.530 & 1726.21 & 0.634 & 2.332 & 22.958 & 0.0000 \\
Oman & 6164.766 & 576.0099 & 0.390 & 2.030 & 25.696 & 0.0000 \\
Abu Dhabi & 3718.572 & 966.901 & -0.112 & 1.399 & 29.171 & 0.0011 \\
Bahrain & 1247.911 & 133.1382 & 0.323 & 1.733 & 22.606 & 0.0000 \\
Dubai & 2835.059 & 1198.683 & 0.269 & 1.738 & 21.019 & 0.0000 \\
& & & & & &
\end{tabular}




\begin{tabular}{|c|c|c|c|c|c|c|}
\hline & Mean & Std. dev. & Skewness & Kurtosis & Jarque-Bera & Prob. \\
\hline \multicolumn{7}{|c|}{ Other Middle East Markets } \\
\hline Jordan & 2059.309 & 97.50865 & -0.38021 & 2.11409 & 15.61856 & 0.0004 \\
\hline Morocco & 9843.326 & 903.1492 & 0.880209 & 2.91714 & 35.58883 & 0.0000 \\
\hline Tunisia & 4865.552 & 394.383 & 0.433705 & 2.20391 & 15.88302 & 0.0003 \\
\hline \multicolumn{7}{|c|}{ European Markets } \\
\hline$\overline{U . K .}$ & 6237.362 & 585.1467 & -0.36748 & 2.22094 & 13.19177 & 0.0013 \\
\hline France & 4047.002 & & -0.10995 & 2.19109 & 8.08102 & 0.0175 \\
\hline Germany & 8642.008 & 1714.733 & -0.01053 & 2.04466 & 10.50097 & 0.0052 \\
\hline \multicolumn{7}{|c|}{ Asian Pacific } \\
\hline Japan & 13860.33 & 3887.743 & 0.010435 & 1.701479 & 19.11472 & 0.0000 \\
\hline China & 8636.03 & 1735.766 & 1.232499 & 4.265093 & 87.00234 & 0.0000 \\
\hline U.S. & 1711.464 & 313.9302 & -0.22757 & 1.532539 & 26.75338 & 0.0000 \\
\hline
\end{tabular}

For Jarque-Bera normality test, the results reported in last column show that the small probability value leads to the rejection of the null hypothesis of a normal distribution for all studied markets.

A simple test for the relationship between stock markets is to consider the correlation coefficients across the data. The results in table (2) show that the Egyptian market has an uphill linear relationship with the GCC markets.

The relation range from weak relationship with Kuwait, moderate with Oman, and strong with other GCC markets. For the other MENA markets, the relation was strong with Jordan, weak with Tunisia, and negative with Morocco. Also Egyptian market has strong positive relation with the European and US markets and weak positive relation with Chinese market.

As expected, the correlation between Abu Dhabi and Dubai appears to be the strongest one with value of $97.8 \%$. The weakest positive correlation among these markets is between Saudi and Tunisia, only $6.29 \%$. For the Egyptian market the strongest correlation relation was with Qatar $92.25 \%$ followed by the correlation with Dubai $91.8 \%$ and the weakest correlation was with Kuwait 20.4\%. Egypt has one negative correlation with Morocco $-25.7 \%$ which may indicate good opportunity for diversification.

This result goes with most of recent studies that show increased correlations in recent decades. Goetzmann et al. (2005) found that over the past few decades, the correlation structure of the world equity markets has increased. Bowman et al. (2010) documented that correlations across markets returns increased gradually.

Many researchers examined the correlation to deduced the advantages of international diversification (Phylaktis and Ravazzolo: 2002: 2005; Lehkonen: 2015; and Bae and Zhang :2015; Bowman et al :2010). Some literatures consider that correlations are poor measure of integration (Forbes and Rigobon :2002 ; Bekaert et al., :2009; and Pukthuanthong and Roll :2009), while, Pukthuanthong and Roll (2009) argue that two markets can be perfectly integrated, and yet still be imperfectly correlated.

Other literatures found that equity diversification are still substantial despite the growing market correlations (Bouslama and Ouda, 2014). Therefore, the study will extend to investigate the co-integrating behavior of the Egyptian stock market with other markets and study the causalities using Granger causality tests. 


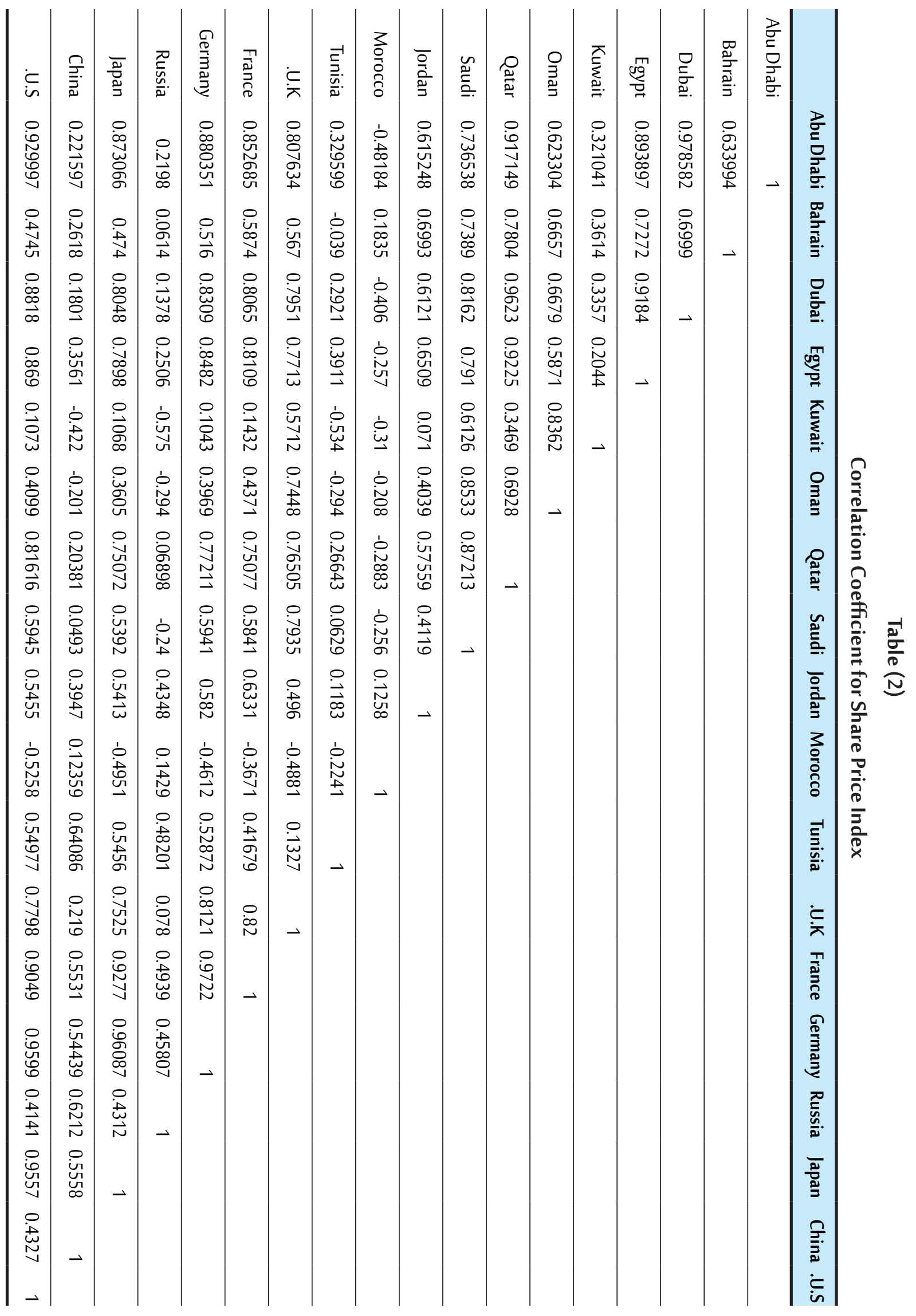




\section{Unit Root Results}

Graphing the share price index in figure (1) suggests that all the data of share price are non-stationary, having intercepts and deterministic trends. The existence of the intercept is concluded from the fact that $y_{t}$ does not seem to be 0 when $y_{t-1}=0$ and the mean of the variables is not zero.
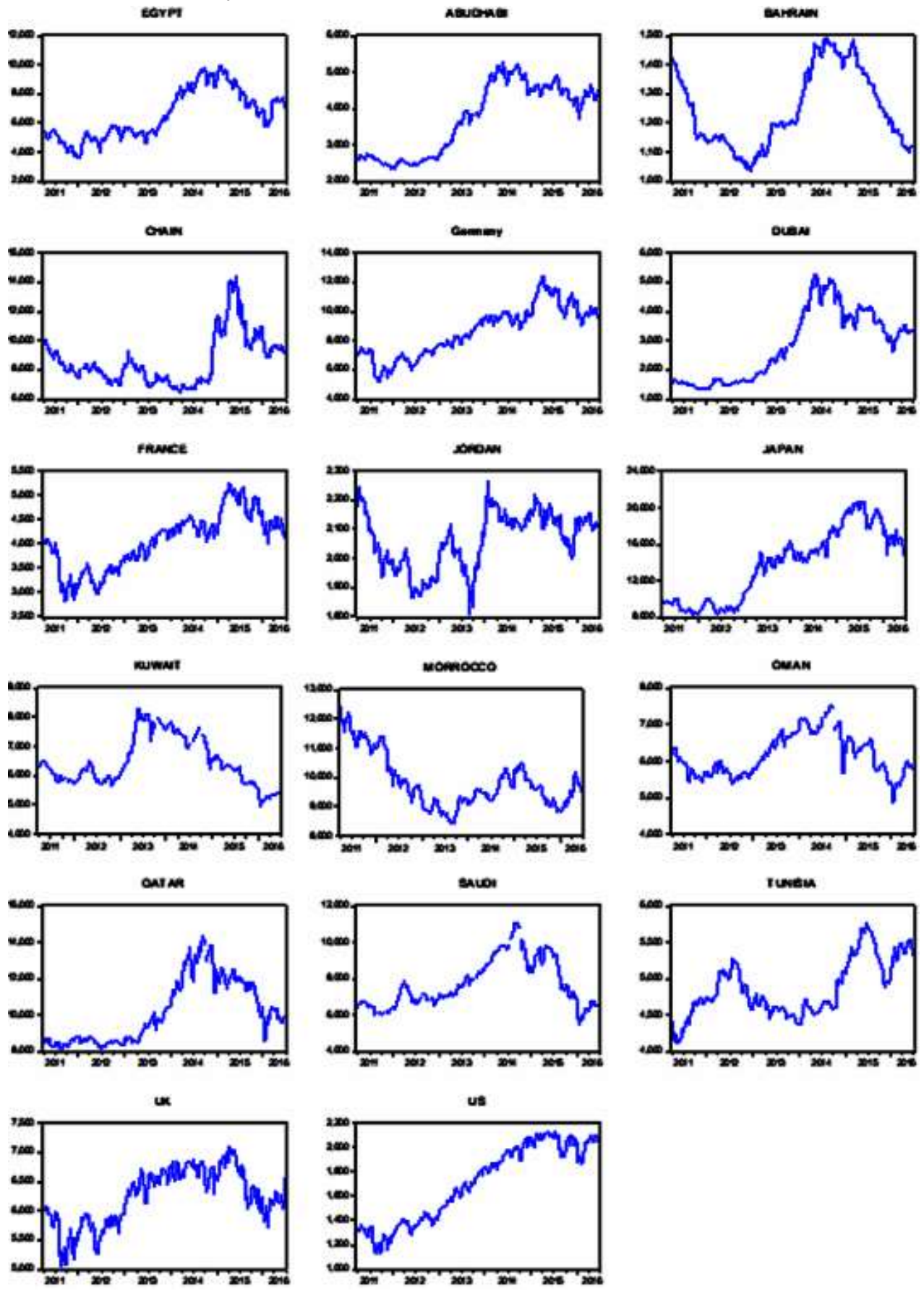

Figure (1) Share Price Index

The results of applying the ADF and PP tests to reveal the presence of the unit root in the series are reported in table (3) and these suggest that the data are time series data which suffer from the existence of 
a unit root. These results imply that it is not possible to use OLS regression analysis to examine the relationship among markets.

Table (3)

Unit Root Tests (The Augmented Dickey-Fuller Regressions)

\begin{tabular}{|c|c|c|c|c|c|}
\hline & & \multicolumn{2}{|c|}{ ADF Unit Root Test } & \multicolumn{2}{|c|}{ PP Unit Root Test } \\
\hline & & t-Statistic & Prob.* & t-Statistic & Prob.* \\
\hline \multirow[t]{2}{*}{1} & Egypt & -1.483357 & 0.8332 & -1.542177 & 0.8127 \\
\hline & GCC Markets & & & & \\
\hline 2 & Kuwait & -0.972452 & 0.9447 & -1.067202 & 0.9314 \\
\hline 3 & Saudi & -0.929863 & 0.9499 & -0.321138 & 0.9897 \\
\hline 4 & Qatar & -0.717212 & 0.9702 & -0.474643 & 0.9842 \\
\hline 5 & Oman & -1.743388 & 0.7292 & -1.214978 & 0.9048 \\
\hline 6 & Abu Dhabi & -1.204432 & 0.9070 & -1.239626 & 0.8996 \\
\hline 7 & Bahrain & -1.207303 & 0.9064 & -1.390817 & 0.8618 \\
\hline \multirow[t]{2}{*}{8} & Dubai & -0.977941 & 0.9441 & -1.054932 & 0.9333 \\
\hline & Other Middle East Markets & & & & \\
\hline 9 & Jordan & -2.830009 & 0.1878 & -2.770711 & 0.2095 \\
\hline 10 & Morocco & -2.254720 & 0.4569 & -2.342616 & 0.4091 \\
\hline \multirow[t]{2}{*}{11} & Tunisia & -1.639938 & 0.7747 & -1.942686 & 0.6293 \\
\hline & European Markets & & & & \\
\hline 12 & U.K. & -2.801077 & 0.1982 & & \\
\hline 13 & France & -2.818348 & 0.1919 & -2.769661 & 0.2099 \\
\hline \multirow[t]{2}{*}{14} & Germany & -2.396016 & 0.3808 & -2.543256 & -2.54326 \\
\hline & Asian Pacific & & & & \\
\hline 15 & Japan & -1.491959 & 0.8303 & -1.594884 & 0.7928 \\
\hline 16 & China & -2.022949 & 0.5857 & -2.242881 & 0.4634 \\
\hline 17 & US & -2.746410 & 0.2189 & -2.746410 & 0.2189 \\
\hline
\end{tabular}

The next step is to select the order of the Vector Autoregressive model (VAR). The lag order of the original VAR model determined by using the sequential modified LR test statistic (LR), Akaike Information Criterion (AIC), Final Prediction Error (FPE), Schwarz Information Criterion (SIC), and Hannan-Quinn information criterion (HQ). The results in Table (4) show that the estimated VAR includes two lags of each variable. This implies that each variable value is affected by the current and the past realizations of the other variables till two lags.

Table (4)

Maximum Lag Length Results

\begin{tabular}{ccccccc}
\hline Lag & LogL & LR & FPE & AIC & SC & HQ \\
\hline 0 & -21730.09 & NA & $5.09 \mathrm{e}+81$ & 236.3814 & 236.6785 & 236.5018 \\
1 & -18207.53 & 6355.928 & $2.80 \mathrm{e}+66^{*}$ & 201.2340 & $206.5806^{*}$ & $203.4011^{*}$ \\
2 & -18016.79 & 308.9216 & $8.73 \mathrm{e}+66$ & 202.3020 & 212.6981 & 206.5157 \\
3 & -17777.47 & 343.3656 & $1.81 \mathrm{e}+67$ & 202.8421 & 218.2877 & 209.1024 \\
4 & -17537.59 & 299.8513 & $4.54 \mathrm{e}+67$ & 203.3760 & 223.8712 & 211.6829 \\
5 & -17217.24 & 341.2399 & $6.40 \mathrm{e}+67$ & 203.0352 & 228.5800 & 213.3889
\end{tabular}




\begin{tabular}{|c|c|c|c|c|c|c|}
\hline Lag & $\log L$ & LR & FPE & AIC & SC & HQ \\
\hline 6 & -16838.43 & 333.5158 & $7.50 \mathrm{e}+67$ & 202.0591 & 232.6534 & 214.4593 \\
\hline \multicolumn{7}{|c|}{ * indicates lag order selected by the criterion } \\
\hline \multicolumn{7}{|c|}{ LR: sequential modified LR test statistic (each test at $5 \%$ level) } \\
\hline \multicolumn{7}{|c|}{ FPE: Final Prediction Error } \\
\hline \multicolumn{7}{|c|}{ AIC: Akaike Information Criterion } \\
\hline \multicolumn{7}{|c|}{ SC: Schwarz Information Criterion } \\
\hline HQ: $\mathrm{Ha}$ & -Quinn infor & n criterion & & & & \\
\hline
\end{tabular}

Both Johansen`s trace and maximum eigenvalue tests are used to test whether the stock markets share price are co-integrated. The maximum possible number of co-integrating vector is equal to the number of variables in the system $(\mathrm{p})$ minus one. Therefore, the minimum possible number of co-integrating vectors is 0 and the maximum will be sixteen (seventeen markets minus one). The maximum eigenvalue statistics and the trace statistics did not reject $\mathrm{r}=16$ at the 95 per cent significance level or at the 90 per cent significance level.

The same results deduced when with bivariate co-integration method. Bivariate co-integration method was used to identify the relationship between the Egyptian market and other markets. For the sake of brevity, the results of the bivariate co-integration of each studied market have been omitted. The results in table (6) show that, using the maximum eigenvalue criteria and the trace criteria, suggest an existence of at least one co-integration relation for all the studied markets.

Table (5)

Co-integration Test Results Based on Johansen Approach.

\begin{tabular}{lcc}
\hline Number of & $\begin{array}{c}\text { Trace } \\
\text { So-integrating vectors }\end{array}$ & $\begin{array}{c}\text { Max-Eigen } \\
\text { Statistics }\end{array}$ \\
\hline None & 913.7480 & 156.7318 \\
At most 1 & 757.0163 & 118.2870 \\
At most 2 & 638.7293 & 100.7353 \\
At most 3 & 537.9940 & 93.34690 \\
At most 4 & $444.6471^{* *}$ & $87.10957^{* *}$ \\
At most 5 & $357.5375^{* *}$ & $67.61916^{* *}$ \\
At most 6 & $289.9184^{* *}$ & $63.83867^{* *}$ \\
At most 7 & $226.0797^{* *}$ & $51.69011^{* *}$ \\
At most 8 & $174.3896^{* *}$ & $46.31152^{* *}$ \\
At most 9 & $128.0781^{* *}$ & $40.93547^{* *}$ \\
At most 10 & $87.14259^{* *}$ & $26.57739^{* *}$ \\
At most 11 & $60.56520^{* *}$ & $25.04851^{* *}$ \\
At most 12 & $35.51669^{* *}$ & $14.06114^{* *}$ \\
At most 13 & $21.45556^{* *}$ & $10.57348^{* *}$ \\
At most 14 & $10.88208^{* *}$ & $6.729615^{* *}$ \\
At most 15 & $4.152465^{* *}$ & $3.635946^{* *}$ \\
At most 16 & $0.516520^{* *}$ & $0.516520^{* *}$ \\
\hline
\end{tabular}


Table ( 6 )

Co-integration Tests for the Share Price

\begin{tabular}{|c|c|c|c|c|}
\hline $\begin{array}{l}\text { Number of } \\
\text { Co- integrating vectors }\end{array}$ & Trace Statistics & $\begin{array}{l}\text { Max-Eigen Sta- } \\
\text { tistics }\end{array}$ & Trace Statistics & $\begin{array}{l}\text { Max-Eigen } \\
\text { Statistics }\end{array}$ \\
\hline Egypt- Abu Dhabi & & & Egypt- Morocco & \\
\hline None & 7.893879** & $7.079561^{* *}$ & $10.40047^{* *}$ & $6.527968 * *$ \\
\hline At most 1 & $0.814317^{* *}$ & $0.814317^{* *}$ & 3.872504 & 3.872504 \\
\hline Egypt- Bahrain & & & Egypt-Tunisia & \\
\hline None & $8.174328^{* *}$ & $7.018911^{* *}$ & $8.007058^{* *}$ & $5.774647^{* *}$ \\
\hline At most 1 & $1.155416^{* *}$ & $1.155416^{* *}$ & $2.232412^{* *}$ & $2.232412^{* *}$ \\
\hline Egypt- Dubai & & & Egypt- U.K. & \\
\hline None & $16.09720^{*}$ & $12.84278^{* *}$ & $8.490102^{* *}$ & $6.523529 * *$ \\
\hline At most 1 & $3.254417^{* *}$ & $3.254417^{* *}$ & $1.966573^{* *}$ & $1.966573^{* *}$ \\
\hline Egypt- Kuwait & & & Egypt- France & \\
\hline None & $6.848926^{* *}$ & $4.511176^{* *}$ & $8.259966^{* *}$ & $6.370772^{* *}$ \\
\hline At most 1 & $2.337750 * *$ & $2.337750^{* *}$ & $1.889194^{* *}$ & $1.889194 * *$ \\
\hline Egypt- Oman & & & Egypt- Germany & \\
\hline None & $7.546024^{* *}$ & $5.470934^{* *}$ & $7.275457^{* *}$ & $7.275457^{* *}$ \\
\hline At most 1 & $2.075091^{* *}$ & $2.075091^{* *}$ & $1.700132^{* *}$ & $1.700132^{* *}$ \\
\hline Egypt- Qatar & & & Egypt-Japan & \\
\hline None & $10.11244^{* *}$ & $8.852647^{* *}$ & $8.405244^{* *}$ & $6.816885^{* *}$ \\
\hline At most 1 & $1.259793^{* *}$ & $1.259793^{* *}$ & $1.588360^{* *}$ & $1.588360 * *$ \\
\hline Egypt-Saudi & & & Egypt-China & \\
\hline None & $6.066022^{* *}$ & $4.127507^{* *}$ & 16.09720 & $12.84278^{* *}$ \\
\hline At most 1 & $1.938515^{* *}$ & $1.938515^{* *}$ & $3.25441^{* *}$ & $3.25441^{* *}$ \\
\hline Egypt- Jordan & & & Egypt- U.S & \\
\hline None & $16.07197^{* *}$ & $13.71541^{* *}$ & $4.049781^{* *}$ & $3.628640 * *$ \\
\hline At most 1 & $2.356560^{* *}$ & $2.356560^{* *}$ & $0.421140^{* *}$ & $0.421140 * *$ \\
\hline
\end{tabular}

Granger-causality test is a strong empirical instrument to determine the direction of interrelationships between variables. Table (7) represents the Granger-causality test the first column represents the dependent variable used in each test and each subsequent column represents independent variables. For example, the p-value of 0.0745 implies rejection the null hypothesis that the change in the Abu Dhabi index ( $\triangle$ Abu Dhabi) does not Granger cause changes in the China index ( $\Delta$ China).

The results reveal strong bidirectional Granger causalities between changes in equity indices in (1) Egypt and Bahrain (2) Egypt and France (3) Dubai and Qatar (4) Qatar and France. Marginal causality exists between (1) Egypt and China.

Bidirectional Granger causalities where the causality from the first country is stronger than the reverse direction exist between (1) Qatar to Abu Dhabi (2) Kuwait to Bahrain (3) Germany to Egypt (4) France to Japan (5) Germany to Egypt (6) Us to Germany (7) Oman to Bahrain (8) Qatar and Dubai (9) Qatar and France.

The results reveal strong unidirectional granger causality from six markets (Abu Dhabi, Bahrain, Qatar, Saudi, Japan, UK, US) to the Egyptian market, while there is strong unidirectional granger causality from 
Egyptian markets to Jordan. The US market has unidirectional granger causality to all of the studied markets except Abu Dhabi, China, Morocco, and Tunisia. The second dominated market was the UK market as it has unidirectional granger causality to all the GCC markets, Jordan, Egypt, and Japan.

Saudi which has largest market capitalization in the GCC and Middle East with ( $\$ 580$ billion) has strong unidirectional Granger causality to all the GCC markets except UAE. Also it has strong unidirectional Granger causality to Jordan. United Arab Emirates (UAE) followed Saudi Arabia by cumulated market capitalization of Dubai and Abu Dhabi is around $\$ 245$ billion. The Abu Dhabi market has strong unidirectional Granger causality to Dubai, Bahrain, Kuwait, and France.

The results reveal existence of strong unidirectional Granger causality from the first to the second markets of the following pairs: (1) France to Bahrain (2) France to Jordan (3) France to Kuwait (4) France to Oman (5) France to Saudi (6) Germany to Bahrain(7) Germany to Japan (8) Germany to Jordan (9) Germany to Kuwait (10) Germany to Saudi (11) Japan to Jordan (12) Japan to Kuwait (13) Kuwait to Oman (14) Morocco to Bahrain (15) Oman to Bahrain (16) Qatar to Bahrain (17) Qatar to Germany (18) Qatar to Japan.

Weak causality deduced from (1) Abu Dhabi to China (2) Abu Dhabi to Oman (3) Abu Dhabi to Qatar (4) Bahrain to Kuwait (5) China to Bahrain (6) Germany to Dubai (7) Germany to France (8) Germany to Oman (9) Morocco to Abu Dhabi (10) Oman to Egypt (11) Qatar to Kuwait (12) Saudi to Dubai (13) Tunisia to Bahrain (14) US to Qatar.

Variance decomposition gives the proportion of the movements in the dependent variables that are due to their "own" shocks, versus shocks to the other variables. Table (8) summarizes the results of the variance decomposition of the Egyptian market. These results show that mostly the variation in the Egyptian market is due to its own changing behavior and the other small change is due to changes in other markets, at the first time horizon 99\% of the Egyptian stock index variance can be attributed to its own movements. The percent gradually declines to $40.5 \%$ and after 10 weeks the Egyptian stock index accounts for its own changes, as this effect from other markets increased as the time period passes A substantial fraction of the EGX variance is associated with Abu Dhabi and Saudi innovations, meaning that these stock markets actively influenced the Egyptian stock market.

The results of the impulse response function are represented in Figures (2). The row data display the time path and the columns display the response of the Egyptian market had on the introduction of a shock in one of the international markets. For example, a one percent increase in standard error of the Abu Dhabi market leads, within ten days, to a 67 percent increase in the standard error of the Egyptian market. It is evident from the figures that there is a persistent effect of shocks on volatility for all countries. It can also be observed that many shock responses tend to arise in a time period of 1-2 days after the shock then persist in this level for very long time.

These results match with Billmeier and Massa (2007) who found that the GCC markets influence the Egyptian stock market. Reportedly during the Saudi stock crisis in 2006, the Cairo and Alexandria Stock Exchange index (CASE 30) index lost about 33 percent between February and June 2006 as a result of the sell-off by GCC investors who faceing margin calls in their home country and had to liquidate some of the foreign equity positions.

Figures (3) shows the response of world markets to the Egyptian market. It seems that the response to the Egyptian shock is very small except of China which is surprisingly, China seems to response the Egyptian shocks. 


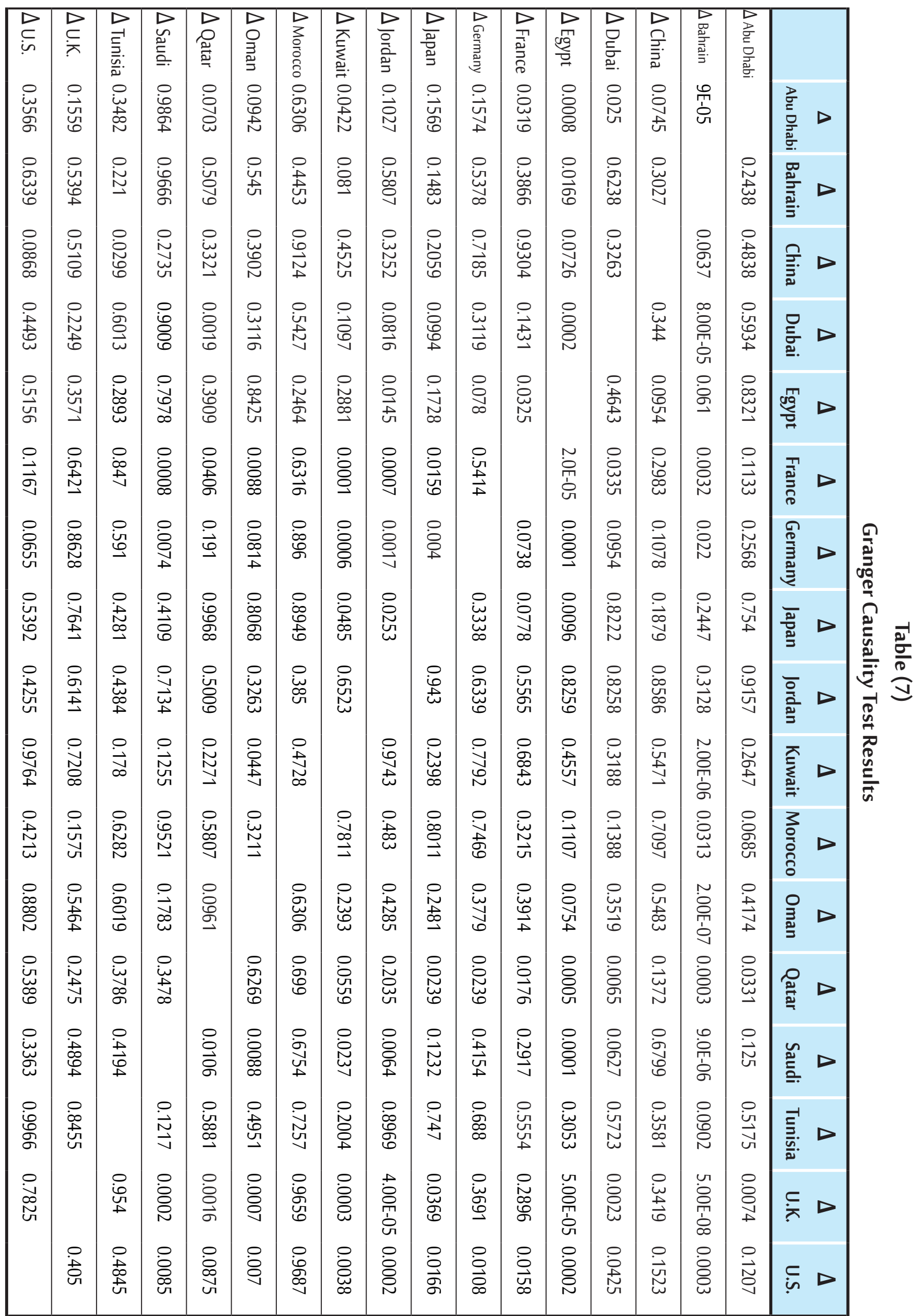




\begin{tabular}{|c|c|c|c|c|c|c|c|c|c|c|c|}
\hline $\overrightarrow{0}$ & 0 & $\infty$ & $v$ & $a$ & u & 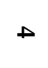 & $\omega$ & $N$ & $\overrightarrow{-}$ & 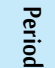 & \multirow{19}{*}{ 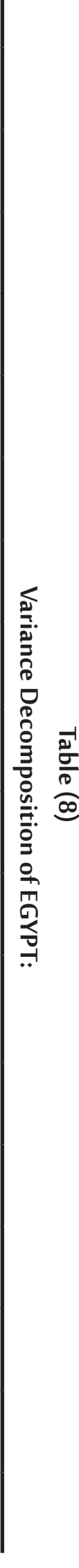 } \\
\hline 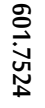 & $\begin{array}{l}\text { U. } \\
\text { : } \\
\text { N. }\end{array}$ & 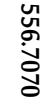 & 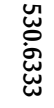 & 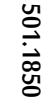 & $\begin{array}{l}\text { 今. } \\
\text { ஸू. } \\
\text { W }\end{array}$ & $\begin{array}{l}\text { N } \\
\text { : } \\
\dot{d} \\
\text { Un }\end{array}$ & 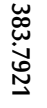 & 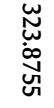 & $\begin{array}{l}\text { N } \\
\stackrel{W}{W} \\
\text { S }\end{array}$ & $i_{i m}^{n}$ & \\
\hline 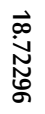 & $\begin{array}{l}\vec{\infty} \\
\stackrel{\leftrightarrow}{0} \\
\stackrel{0}{0}\end{array}$ & $\begin{array}{l}\vec{\infty} \\
\stackrel{N}{\vec{\omega}} \\
\stackrel{\vec{\omega}}{\sigma}\end{array}$ & 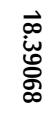 & $\begin{array}{l}\vec{N} \\
\stackrel{8}{\$} \\
\stackrel{\Xi}{ \pm}\end{array}$ & 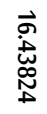 & 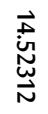 & $\begin{array}{l}\overrightarrow{\dot{\sigma}} \\
\overrightarrow{\vec{D}}\end{array}$ & 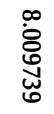 & 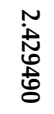 & $\begin{array}{l}\text { D } \\
\text { D } \\
\text { D } \\
\text { W }\end{array}$ & \\
\hline 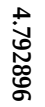 & 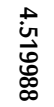 & $\begin{array}{l}\underset{\sim}{\sim} \\
\underset{\mathbb{U}}{\mathbb{U}}\end{array}$ & $\begin{array}{l}w \\
\dot{\delta} \\
\text { Oे } \\
\hat{f}\end{array}$ & $\begin{array}{l}\omega \\
\stackrel{\omega}{*} \\
\tilde{E}\end{array}$ & $\begin{array}{l}\omega \\
\dot{\omega} \\
\stackrel{\vec{\omega}}{\vec{\omega}}\end{array}$ & 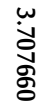 & 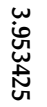 & 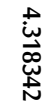 & $\begin{array}{l}\overrightarrow{\tilde{\sigma}} \\
\vec{\varpi} \\
\vec{\Xi}\end{array}$ & $\begin{array}{l}\text { 罢 } \\
\text { 䘚 } \\
\text { Z }\end{array}$ & \\
\hline 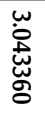 & 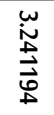 & 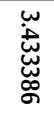 & 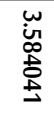 & $\begin{array}{l}\omega \\
\dot{\omega} \\
\overrightarrow{0} \\
\dot{G}\end{array}$ & $\begin{array}{l}\omega \\
\mathbf{N} \\
\mathbb{W} \\
\mathbb{D}\end{array}$ & 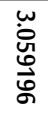 & 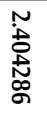 & $\begin{array}{l}\tilde{\tilde{O}} \\
\overrightarrow{\tilde{N}} \\
\text { Vे }\end{array}$ & $\begin{array}{l}\dot{\overrightarrow{\hat{N}}} \\
\overrightarrow{\tilde{N}} \\
\text { On }\end{array}$ & $\frac{\hat{T}}{\bar{z}}$ & \\
\hline $\begin{array}{l}\text { 离 } \\
\text { 点 }\end{array}$ & $\begin{array}{l}\overrightarrow{\dot{\omega}} \\
\text { } \\
\stackrel{\tilde{N}}{\sim}\end{array}$ & $\begin{array}{l}\overrightarrow{\dot{\delta}} \\
\overrightarrow{0} \\
\vec{\sigma}\end{array}$ & $\begin{array}{l}\overrightarrow{\tilde{\tilde{V}}} \\
\text { t }\end{array}$ & $\begin{array}{l}\overrightarrow{\omega_{w}} \\
\vec{w} \\
\vec{N}\end{array}$ & 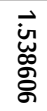 & $\begin{array}{l}\overrightarrow{\dot{o}} \\
\text { ज्: } \\
\text { oু }\end{array}$ & 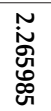 & $\begin{array}{l}\tilde{W} \\
\tilde{W} \\
\tilde{w} \\
\tilde{W}\end{array}$ & 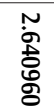 & $\stackrel{\text { 모 }}{\text { ㅁ }}$ & \\
\hline 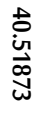 & 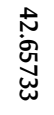 & 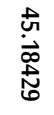 & 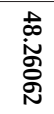 & $\begin{array}{l}\text { v } \\
\dot{0} \\
\dot{0} \\
\dot{0}\end{array}$ & 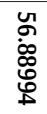 & 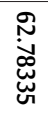 & $\begin{array}{l}\text { : } \\
\text { ப் } \\
\text { 워 }\end{array}$ & 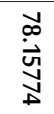 & 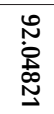 & 鮁 & \\
\hline 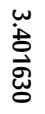 & 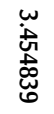 & 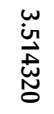 & 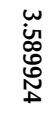 & $\begin{array}{l}\omega \\
\hat{0} \\
\tilde{:} \\
0 \\
0\end{array}$ & 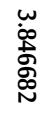 & 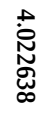 & 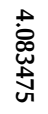 & 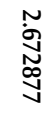 & $\begin{array}{l}\text { o. } \\
\text { ठे } \\
\text { ठे }\end{array}$ & 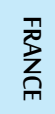 & \\
\hline 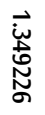 & $\begin{array}{l}\dot{\overrightarrow{\vec{N}}} \\
\text { 芯 } \\
\text { 荧 }\end{array}$ & 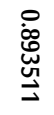 & 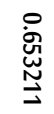 & 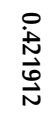 & 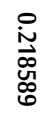 & 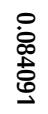 & 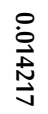 & $\begin{array}{l}\stackrel{P}{\dot{\theta}} \\
\text { ज्ञ } \\
\dot{v}\end{array}$ & $\begin{array}{l}\text { oे } \\
\text { ठे } \\
\text { ठ }\end{array}$ & 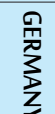 & \\
\hline 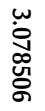 & $\begin{array}{l}\text { No } \\
\text { ơ⿱口丂 } \\
\text { 䓪 }\end{array}$ & 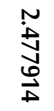 & 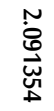 & 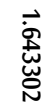 & $\begin{array}{l}\dot{\overrightarrow{\vec{v}}} \\
\text { ü } \\
\dot{\omega}\end{array}$ & 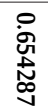 & 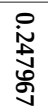 & 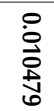 & $\begin{array}{l}\text { Oे } \\
\text { ठें } \\
\text { ठ }\end{array}$ & $\bar{z}_{\frac{1}{2}}$ & \\
\hline 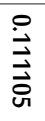 & $\begin{array}{l}\stackrel{P}{\vec{t}} \\
\dot{\vec{t}} \\
\dot{f}\end{array}$ & $\begin{array}{l}\stackrel{P}{\vec{N}} \\
\text { N }\end{array}$ & 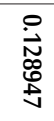 & 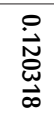 & 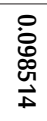 & $\begin{array}{l}\text { Oे } \\
\dot{0} \\
\stackrel{0}{N} \\
\text { N }\end{array}$ & $\begin{array}{l}\text { Oे } \\
\dot{\tilde{N}} \\
\stackrel{ \pm}{\omega} \\
\end{array}$ & 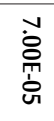 & $\begin{array}{l}\text { 여 } \\
\text { ठे }\end{array}$ & $\begin{array}{l}\overline{0} \\
\text { ㅁ } \\
\bar{z}\end{array}$ & \\
\hline 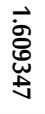 & 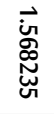 & $\underset{\substack{\overrightarrow{\mathrm{i}} \\
\mathrm{i}}}{\overrightarrow{\mathrm{w}}}$ & 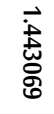 & $\begin{array}{l}\vec{\omega} \\
\vec{w} \\
\text { w } \\
\end{array}$ & $\begin{array}{l}\vec{N} \\
\text { ث્ث } \\
\text { ठ }\end{array}$ & $\begin{array}{l}\overrightarrow{\dot{0}} \\
\text { do } \\
\text { जे }\end{array}$ & 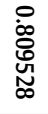 & $\begin{array}{l}\text { on } \\
\text { 足 } \\
\text { 节 }\end{array}$ & $\begin{array}{l}\text { ठे } \\
\text { ठे } \\
\text { ठ }\end{array}$ & $\sum_{\equiv}^{\pi}$ & \\
\hline 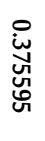 & 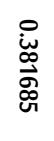 & 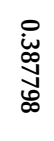 & $\begin{array}{l}\text { i. } \\
\text { ర్జ } \\
\text {. }\end{array}$ & 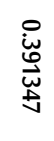 & 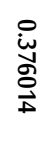 & $\begin{array}{l}\stackrel{0}{\mathrm{w}} \\
\text { 岕 } \\
\text { जू }\end{array}$ & $\begin{array}{l}\stackrel{0}{\tilde{N}} \\
\stackrel{+}{ \pm}\end{array}$ & 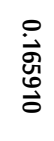 & $\begin{array}{l}\text { ठे } \\
\text { ठे }\end{array}$ & 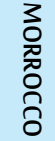 & \\
\hline 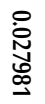 & 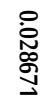 & 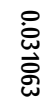 & $\begin{array}{l}\text { Oे } \\
\text {. } \\
\text { 索 }\end{array}$ & $\begin{array}{l}\text { Oे } \\
\text { 芯 } \\
\text {. }\end{array}$ & 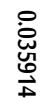 & 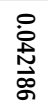 & $\begin{array}{l}\text { Oे } \\
\text { N } \\
\text { O̊ }\end{array}$ & $\begin{array}{l}\text { Oे. } \\
\text { : } \\
\text { ర్రీ }\end{array}$ & $\begin{array}{l}\text { Oे } \\
\text { ठे }\end{array}$ & $\stackrel{0}{3}$ & \\
\hline 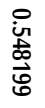 & $\begin{array}{l}\text {. } \\
\text { i్ } \\
\text { 心 } \\
\sigma\end{array}$ & 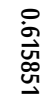 & 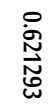 & $\begin{array}{l}\text { 엄 } \\
\text { in } \\
\text { in }\end{array}$ & $\begin{array}{l}\text { P } \\
\text { 离 } \\
\text { 心్山 }\end{array}$ & 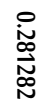 & $\begin{array}{l}\stackrel{P}{\vec{N}} \\
\stackrel{U}{\vec{\Xi}}\end{array}$ & $\begin{array}{l}\dot{P} \\
\dot{\vec{D}} \\
\dot{\vec{H}} \\
\overrightarrow{\vec{D}}\end{array}$ & $\begin{array}{l}\text { 여 } \\
\text { ठे }\end{array}$ & $\begin{array}{l}\text { 㺼 } \\
\text { 离 }\end{array}$ & \\
\hline 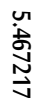 & 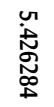 & 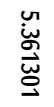 & $\begin{array}{l}\tilde{u} \\
\stackrel{\tilde{w}}{\vec{\omega}} \\
\end{array}$ & 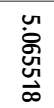 & 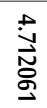 & $\begin{array}{l}\overrightarrow{\dot{0}} \\
\dot{\mathrm{g}} \\
\dot{\mathscr{\omega}}\end{array}$ & $\begin{array}{l}\tilde{\tilde{\sigma}} \\
\stackrel{\sim}{\vec{\Xi}}\end{array}$ & $\begin{array}{l}\overrightarrow{\vec{\phi}} \\
\text { 岕 } \\
\end{array}$ & 잉 & $\begin{array}{l}\stackrel{u}{\mathcal{E}} \\
\underline{\underline{D}}\end{array}$ & \\
\hline $\begin{array}{l}\text { : } \\
\stackrel{\leftrightarrow}{\mathscr{W}} \\
\pm \\
\pm\end{array}$ & $\begin{array}{l}\text { 总 } \\
\text { 岕 } \\
\text {. }\end{array}$ & 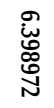 & 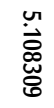 & $\begin{array}{l}\omega \\
\dot{\infty} \\
\mathbf{0} \\
\mathbb{0} \\
\mathbb{f}\end{array}$ & \begin{tabular}{l}
$\tilde{\tilde{\sigma}}$ \\
\multirow{\Xi}{*}{}
\end{tabular} & $\begin{array}{l}\overrightarrow{\mathrm{ஸ}} \\
\text { 岕 } \\
\text { }\end{array}$ & 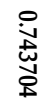 & 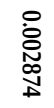 & $\begin{array}{l}\text { ठे } \\
\text { ठ̊ }\end{array}$ & $\begin{array}{l}\text { ज. } \\
\text { s. }\end{array}$ & \\
\hline 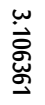 & 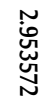 & 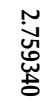 & 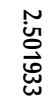 & 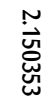 & 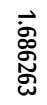 & 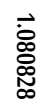 & $\begin{array}{l}\text { D } \\
\text { ث્ } \\
\text { N }\end{array}$ & 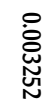 & $\begin{array}{l}\text { ठे } \\
\text { ठे }\end{array}$ & $\begin{array}{l}{ }_{\underline{Z}}^{-1} \\
\frac{\mathrm{M}}{D}\end{array}$ & \\
\hline 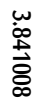 & 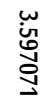 & $\begin{array}{l}\underset{\tilde{H}}{\tilde{\Phi}} \\
\text { w్ర }\end{array}$ & $\begin{array}{l}\text { N } \\
\text { d } \\
\text { N }\end{array}$ & $\begin{array}{l}\tilde{\vec{b}} \\
\text { 总 } \\
\text { on }\end{array}$ & 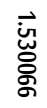 & 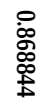 & $\begin{array}{l}\stackrel{O}{W} \\
\stackrel{\Phi}{\Phi} \\
\stackrel{\Phi}{\omega}\end{array}$ & $\begin{array}{l}\text { Oे } \\
\text {. } \\
\text { 总 }\end{array}$ & $\begin{array}{l}\text { ठे } \\
\text { ठ̊ }\end{array}$ & 듯 & \\
\hline
\end{tabular}



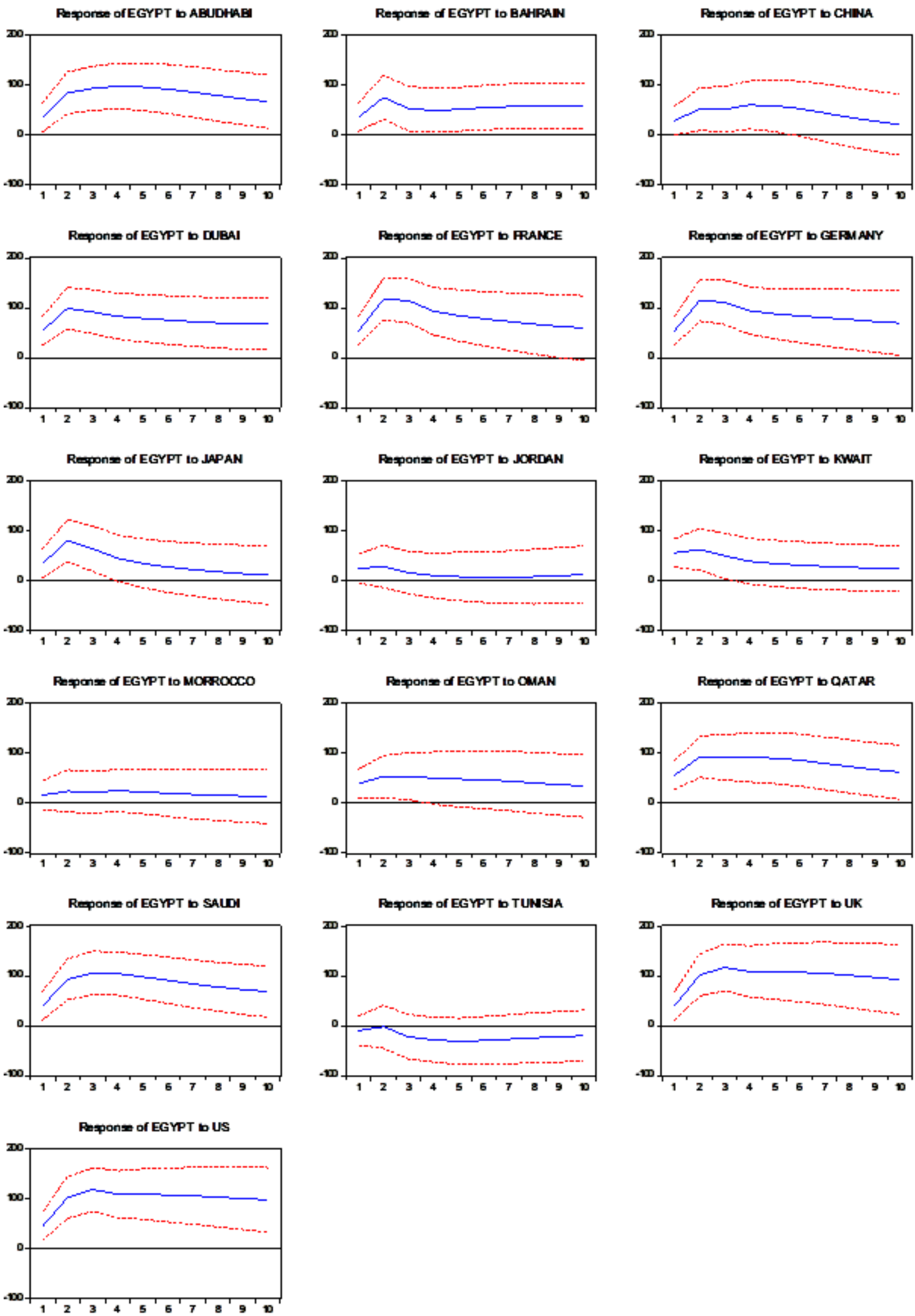

Figure (2) Impulse Response Function for the Egyptian Markets to World Markets 

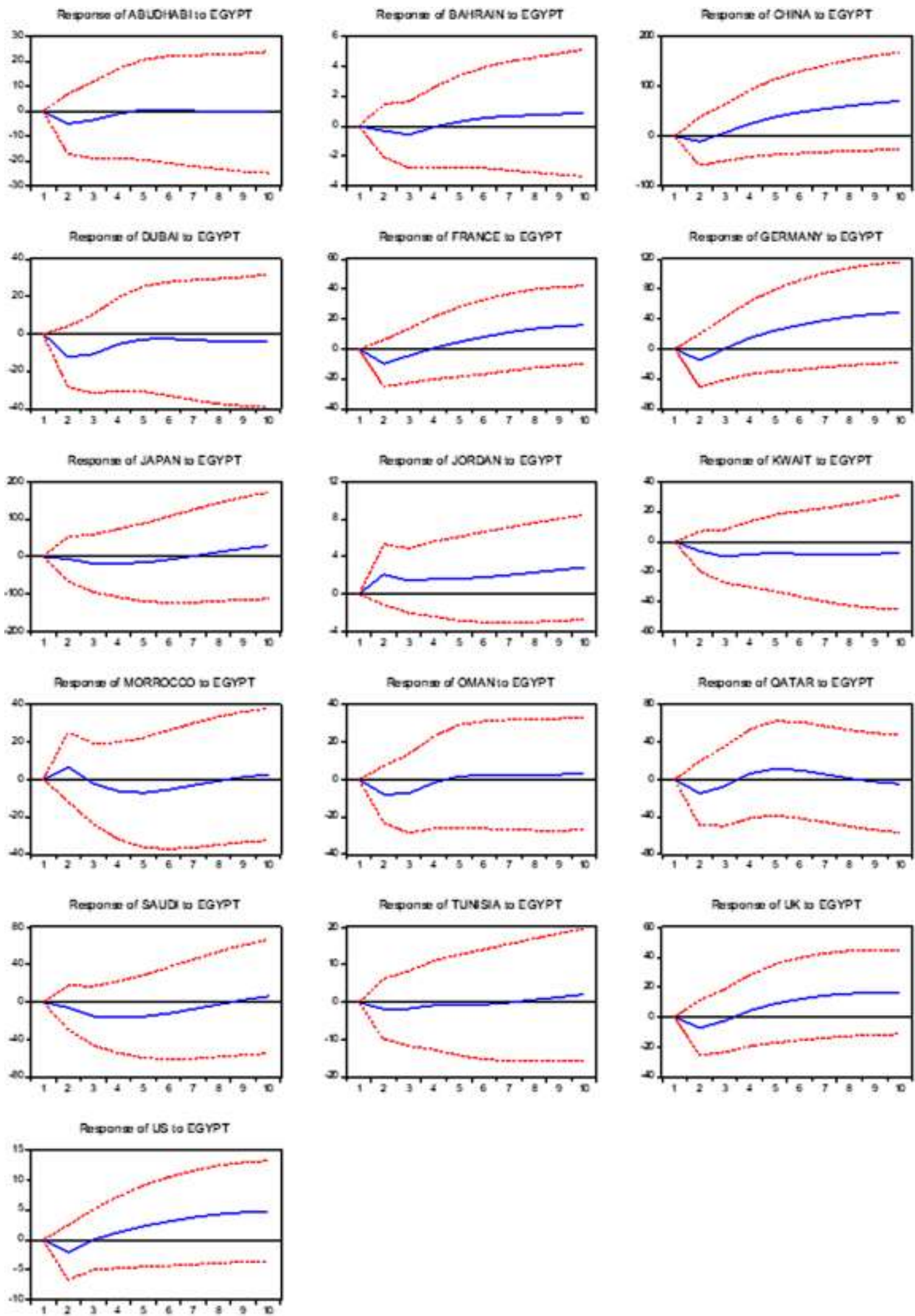

Figure (3) Impulse Response Function for the World Markets to Egyptian Markets 


\section{Portfolio Optimization}

This study adopts the portfolio optimization approach to examine the preferences of different internationally diversified portfolios and domestic portfolio for risk-averse investors. The weekly return used to compose the portfolios. The weekly returns calculated as the natural logarithmic differences in price, $\left(R_{i}\right.$ $=\ln [\mathrm{Pt} / \mathrm{Pt}-1])$. Summary statistics for the stock price index series are given in Table (9). It can be seen that eleven markets have negative average returns, which reflect in negative means. Egypt, Abu Dhabi, Dubai, Qatar, Japan and US have positive average return. On other hand, these countries have the highest standard deviation which denotes the highest market volatility. None of the markets proves to have normally distributed returns as the probability that a Jarque-Bera statistic exceeds (in absolute value) the observed value under the null hypothesis.

Table (9)

Descriptive Statistics for Stock Indices Weakly Return

\begin{tabular}{|c|c|c|c|c|c|c|}
\hline & Mean & Std. dev. & Skewness & Kurtosis & Jarque-Bera & Prob. \\
\hline Egypt & 0.000871 & 0.047511 & -0.47776 & 2.785161 & 86.38606 & 0.0000 \\
\hline \multicolumn{7}{|c|}{ GCC Markets } \\
\hline Kuwait & -0.0010 & 0.029083 & -0.399 & 2.125985 & 49.21538 & 0.0000 \\
\hline Saudi & -0.00048 & 0.034247 & -0.65154 & 2.343245 & 67.63518 & 0.0000 \\
\hline Qatar & 0.000193 & 0.03452 & -0.29517 & 2.294776 & 50.95133 & 0.0000 \\
\hline Oman & -0.00016 & 0.032253 & -0.22638 & 4.511912 & 185.1944 & 0.0000 \\
\hline Abu Dhabi & 0.001363 & 0.033326 & -0.34707 & 1.470882 & 26.47031 & 0.0000 \\
\hline Bahrain & -0.00118 & 0.027016 & -0.6956 & 2.66417 & 20.24806 & 0.0000 \\
\hline Dubai & 0.002334 & 0.04448 & -0.34312 & 1.37604 & 13.91301 & 0.0000 \\
\hline \multicolumn{7}{|c|}{ Other Middle East Markets } \\
\hline Jordan & -0.00045 & 0.027669 & -0.27857 & 2.769593 & 78.60457 & 0.0000 \\
\hline Morocco & -0.00194 & 0.029274 & -0.81843 & 2.525617 & 96.12201 & 0.0000 \\
\hline Tunisia & -0.00042 & 0.026868 & -0.49421 & 2.169376 & 58.87690 & 0.0000 \\
\hline \multicolumn{7}{|c|}{ European Markets } \\
\hline U.K. & -0.00112 & 0.03194 & -0.54829 & 2.486997 & 80.95330 & 0.0000 \\
\hline France & -0.00129 & 0.036039 & -0.56332 & 1.725636 & 41.40585 & 0.0000 \\
\hline Germany & -0.00021 & 0.037509 & -0.69781 & 2.154658 & 63.72671 & 0.0000 \\
\hline \multicolumn{7}{|c|}{$\underline{\text { Asian Pacific }}$} \\
\hline Japan & 0.000756 & 0.041246 & -0.45042 & 0.926084 & 15.73959 & 0.0000 \\
\hline China & -0.00014 & 0.040957 & 0.10354 & 1.61136 & 25.09330 & 0.0000 \\
\hline U.S. & 0.00043 & 0.031013 & -0.71462 & 3.135537 & 118.8666 & 0.0000 \\
\hline
\end{tabular}

Figure (4) exhibit the average weekly returns versus standard deviation, it shows that EGX30 return does not dominated according to the mean-variance efficient. The results match with the results of AlKulaib et al. (2009) how found that the UAE's stock market leads all the markets in the region. They attribute this to the tremendous growth of the UAE's equity market in recent year. 


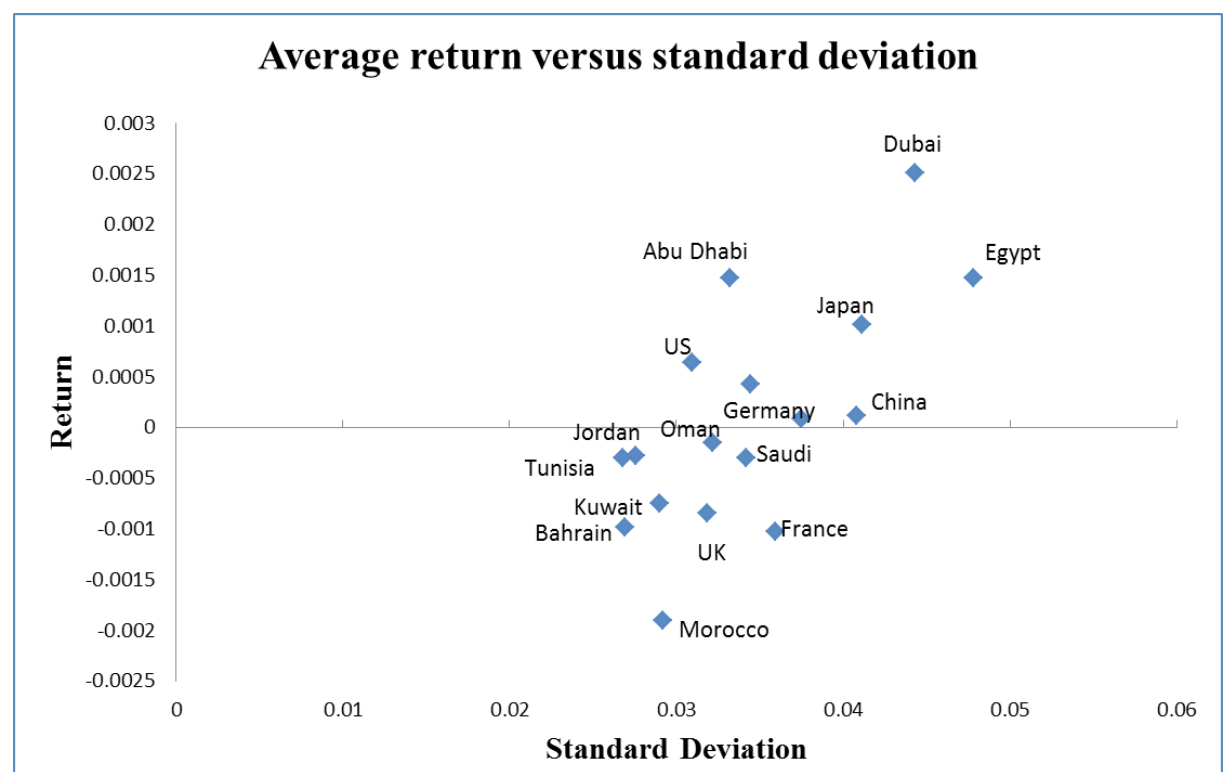

Figure (4) Average Weekly Returns Versus Standard Deviation

The portfolio was imposed the constraints of no short sales meaning investment positions of each sector spans between $0 \%$ and $100 \%$ of the portfolio. From figure (5) it can be concluded that when applying the mean-variance optimization approach to different efficient frontiers, the internationally diversified portfolios dominate domestic portfolio performance in the entire risk-return range.

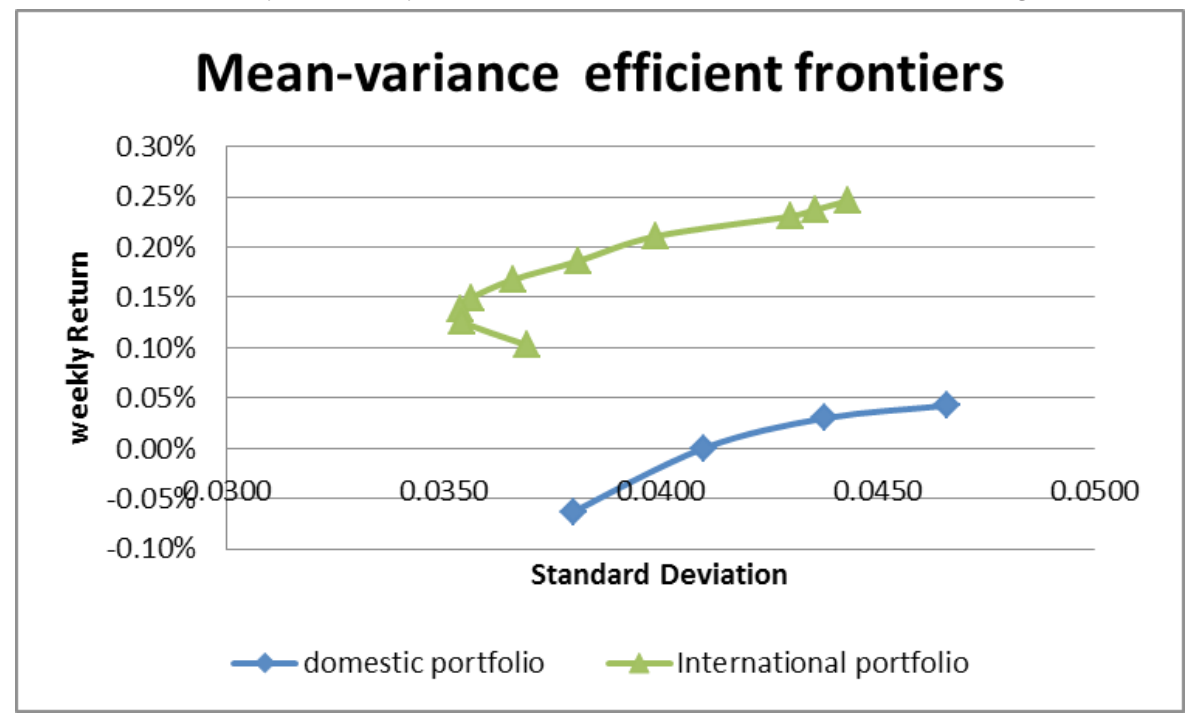

Figure (5) Mean Variance Efficient Frontiers

Figure (6) shows a comparison between different composed portfolios. The first portfolios start with the domestic portfolio then international equities was added respectively as following: GCC equities, the three remaining MENA equities, the European equities, then the Asian equities, and finally the US`s equities. The results concluding that notable gain achieved when adding GCC equities to the domestic portfolio. However the small linkage with Tunisia, Jordon, and morocco no significant gains have been achieved by 
adding them to the internationally diversified portfolios. As expected, a notable gains achieved from adding the Asian markets to the international portfolio.

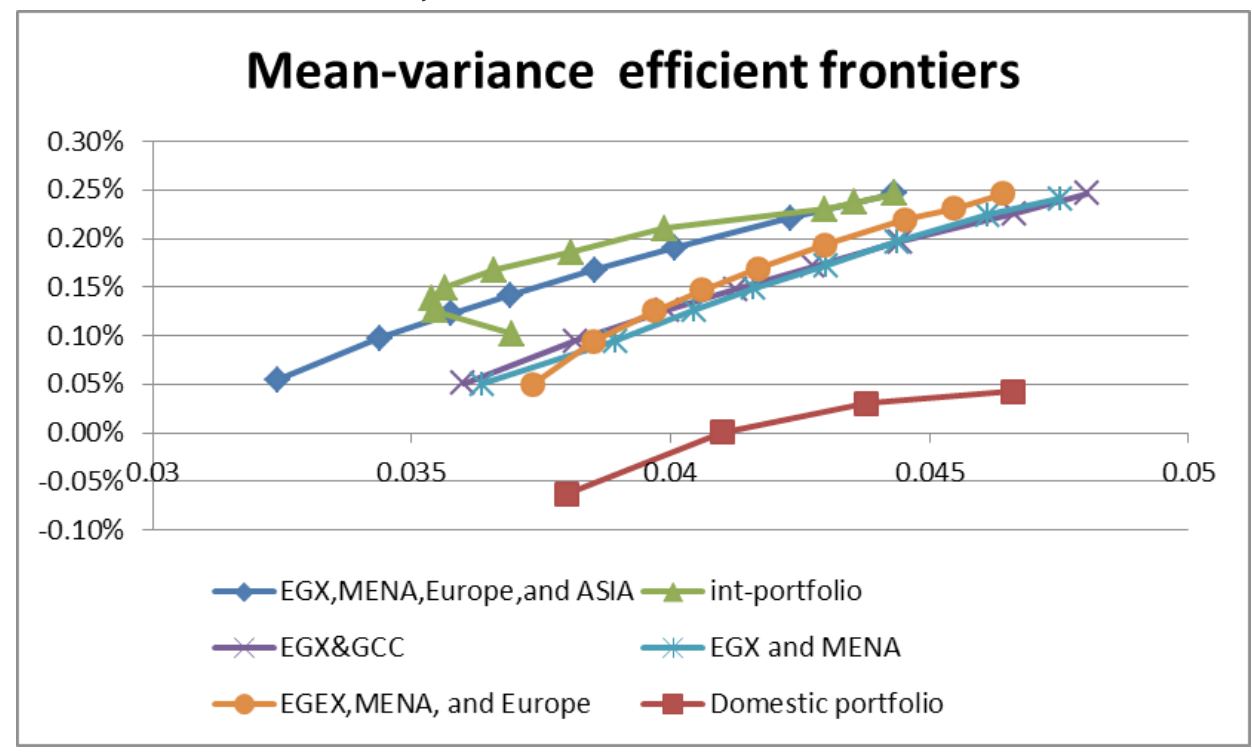

Figure (6) Mean Variance Efficient Frontiers for Different International Portfolios.

Figure (7) exhibits the suggested international portfolio which minimizes the risk. The domestic component weights $31 \%$. However the high degree of linkage with the UAE market, it is dominated in the portfolio with weights around 44\% (35\% for Dubai and 9\% for Abu Dhabi), Followed by Japan with 13\%. All other MENA markets did not exceed $1 \%$ for each.

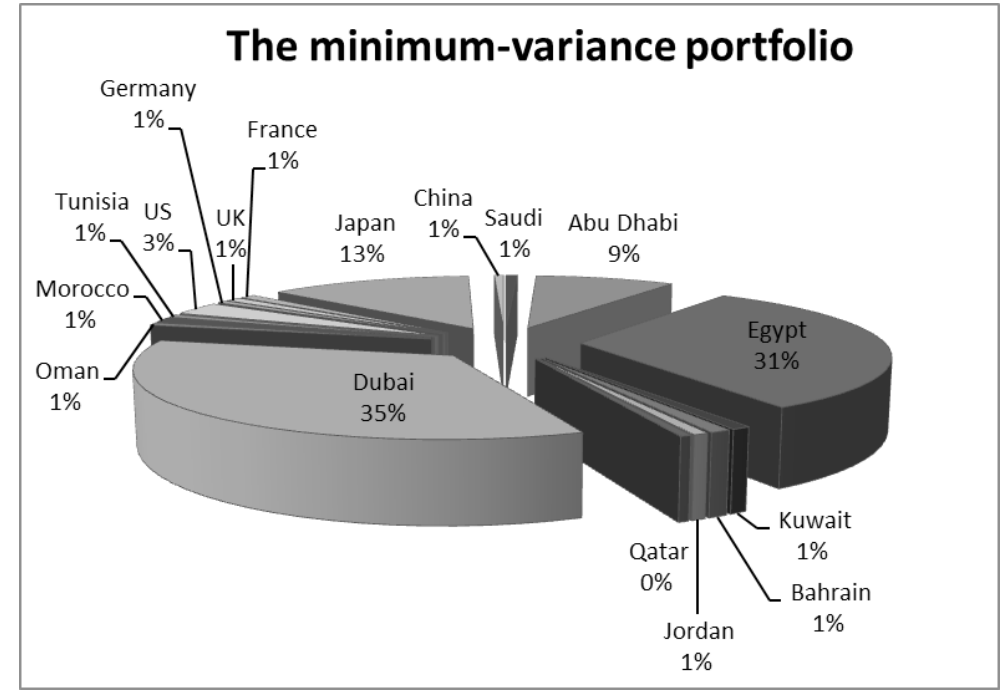

Figure (7) Weights of the Minimum-variance International Portfolio

\section{Result Interpretation}

In 2008, Rim \& Setaputra argue that financial integration is thought to be the result of the openness of markets to foreign investors and as financial markets become more open, it is expected the degree of integration to increases. The results show that the Egyptian market is significantly integrated to the world 
market. This fact could be interpreted as a result of the foreign capital flowing in the Egyptian market. For example, as shown in table (10) in 2015 among more than 18 thousands new investors who registered to the market $15 \%$ of which are foreigner.

Foreigners accounted for about $29 \%$ of the total value traded in 2011, of which more than $24 \%$ was captured by non-Arab foreign investors, while the remaining $5 \%$ was captured by Arab investors and increased to $8 \%$ by 2015, after excluding deals and bonds, which interpret the significant integration of the Egyptian market with the GCC markets.

The foreign participation by region, Europe has dominated foreign investments on EGX its participation range from capturing around 49\% in 2011 to around 39\% in 2015of the total foreign investments, after excluding deals and bonds. Arab investments increased from 18\% in 2011 to 30\% of the foreign investments, while 19\% were owed to USA \& Canada in 2015 compared to 27\% in 2011. At the country level, the USA and the United Kingdom have represented $18 \%$ and $17 \%$, respectively, of the total foreign investments on EGX in 2015, followed by Saudi Arabia constituting around 14\% the total foreign investments, after excluding deals and bonds.

\section{Table (10)}

Foreign Participation in the Egyptian Exchange

\begin{tabular}{lcccccc}
\hline \multirow{2}{*}{ Years } & \multicolumn{2}{c}{ Number of Newly Coded Investors } & \multicolumn{3}{c}{ Value Traded\% } \\
\cline { 2 - 7 } & Egyptians & Arabs & Non-Arab Foreigners & Egyptians & Arabs & Non-Arab Foreigners \\
\hline 2011 & 33569 & 886 & 1597 & $71 \%$ & $5 \%$ & $24 \%$ \\
2012 & 20082 & 742 & 1398 & $79 \%$ & $6 \%$ & $15 \%$ \\
2013 & 14693 & 538 & 1076 & $79.8 \%$ & $6.1 \%$ & $14.1 \%$ \\
2014 & 19621 & 571 & 1480 & $79.1 \%$ & $8.1 \%$ & $12.8 \%$ \\
2015 & 15219 & 733 & 2046 & $72.4 \%$ & $8.2 \%$ & $19.4 \%$ \\
\hline
\end{tabular}

\begin{tabular}{lllllllll}
\hline \multirow{2}{*}{ Years } & \multicolumn{3}{l}{ Foreign Participation by Region } & \multicolumn{5}{l}{ Foreign Participation by Country } \\
\cline { 2 - 8 } & US \& Canada & Europe & Arabs & Others & USA & UK & Saudi & Others \\
\hline 2011 & $27 \%$ & $49 \%$ & $18 \%$ & $6 \%$ & $27 \%$ & $41 \%$ & $8 \%$ & $23 \%$ \\
2012 & $23 \%$ & $41 \%$ & $29 \%$ & $7 \%$ & $23 \%$ & $32 \%$ & $15 \%$ & $31 \%$ \\
2013 & $20 \%$ & $43 \%$ & $30 \%$ & $7 \%$ & $19 \%$ & $32 \%$ & $14 \%$ & $35 \%$ \\
2014 & $16 \%$ & $36 \%$ & $39 \%$ & $9 \%$ & $15 \%$ & $22 \%$ & $20 \%$ & $43 \%$ \\
2015 & $19 \%$ & $39 \%$ & $30 \%$ & $12 \%$ & $18 \%$ & $17 \%$ & $14 \%$ & $51 \%$ \\
\hline
\end{tabular}

Source: the Annual Report of the Egyptian Stock Exchange, various issues.

\section{Conclusion}

The study investigates the potential benefits of the Egyptian investors that may be gained from international portfolio diversification across different markets. Previous literatures argue that the benefits from international diversification depend on the relationships among stock markets and the degree of their independence. Hence, firstly long-run relationship has been investigated both bilaterally and between different 
markets. Correlation, Johansen co-integration, Granger causality test, variance decompositions and impulse responses have been applied. Secondly, the mean-variance portfolio optimization approach applied to investigate the preferences for international diversification. The results indicate that the Egyptian market and the studied markets are interdependent and highly integrated.

Performing correlation coefficients, reveal strong relation with most of the GCC, European and US markets. For the MENA markets, the relation was strong with Jordan, and weak with Tunisia, and negative with Morocco. Egypt has weak positive relation with China.

Performing co-integration analysis, according to Engle and Granger (1987) and Johansen (1988) reveal that markets have a long-run relationship as sixteen co-integrating vectors have been founded. The bivariate co-integration results suggest an existence of co-integration relation for the Egyptian market with all the studied markets.

Performing, Granger-causality test deduced strong bidirectional Granger causalities between changes in equity indices in Egypt and two markets; Bahrain and France. Marginal causality exists between Egypt and China. The results deduced strong unidirectional granger causality from six markets (Abu Dhabi, Bahrain, Qatar, Saudi, Japan, UK, US) to the Egyptian market, while there is strong unidirectional granger causality from the Egyptian markets to Jordan. The existence of Granger causality implies that the differences between the markets are insufficient for Egyptian investors to achieve gains by diversifying internationally. Similar results deduced when applying variance decomposition and impulse response.

The general conclusion of this study is that the Egyptian stock market tends to display stronger linkages with GCC markets and MENA more than the linkage with the world markets.

The mean-variance optimization approach deduced that however, the high degree of integration Egyptian investors, they still can gain some benefits from international diversification.

These results match with the results if Li et al. (2003) who argue that even that global markets have become more integrated, it does not negate the benefits of international diversification in emerging markets.

\section{Future Research}

This research could be expanded in the several ways. The stock markets could be tested for diversification opportunities during a financial crisis as the markets usually tend to move together more closely during turbulent periods. It also, could be expanded by investigating Egyptian market volatility with GARCH approach. 


\section{References}

- Ahlgren, N. and J. Antell. (2002). "Testing for Cointegration between International Stock Prices", Applied Financial Economics, 12 (12): 851-861.

- Al Kulaib, Y. A.; M. Najand and A. Mashayekh. (2009). “Dynamic Linkages among Equity Markets in the Middle East and North African Countries", Journal of Multinational Financial Management, 19:43-53.

- Bae, K. H. and X. Zhang. (2015). "The Cost of Stock Market Integration in Emerging Markets", Asia-Pacific Journal of Financial Studies, 44 (1): 1-23.

- Bekaert, G.; R. J. Hodrick and X. Zhang. (2009). International Stock Return Comovements", Journal of Finance, 64: 2591-2626

- Bessler, D. A. and J. Yang. (2003). "The Structure of Interdependence in International Stock Markets", Journal of International Money and Finance 22: 261-287.

- Billmeier, A. and I. Massa. (2007a). Go Long or Short in Pyramids: News from the Egyptian Stock Market. IMF Working Paper No. 07/179. Washington D.C: International Monetary Fund.

- Bley, J. (2007). "How Homogeneous are the Stock Markets of the Middle East and North Africa?", Quarterly Review of Business and Economics, 46 (3): 3-26.

- Bouslama, O. and O. B. Ouda. (2014). "International Portfolio Diversification Benefits: The Relevance of Emerging Markets", International Journal of Economics and Finance, 6, (3):200.

- Bowman, R. G.; K. F. Chan and M. R. Comer. (2010). “Diversification, Rationality and the Asian Economic Crisis", Pacific-Basin Finance Journal, 18 (1): 1-23.

- Carrieri, F.; V. Errunza and K. Hogan. (2007). "Characterizing World Market Integration through Time", Journal of Financial and Quantitative Analysis, 42: 915-940.

- Cheol, E. S.; W. Huang and L. Sandy. (2008). "International Diversification with Large and Small Cap stocks", Journal of Financial and Quantitative Analysis, 43 (2) :489-524.

- Darrat A. F.; K. Elkhal and S. R. Hakim. (2000). “On the Integration of Emerging Stock Markets in the Middle East", J. Econ. Dev., 25 (2): 119-129

- DeFusco, R.; J. M. Geppert and G. P. Tsetsekos. (1996). “Long-run Diversification Potential in Emerging Stock Markets", The Financial Review, 31 (2): 343- 363.

- De Jong, F. and F. De Roon. (2005). "Time-varying Market Integration and Expected Returns in Emerging Markets", Journal of Financial Economics, 78: 583-613.

- Dekker, A.; K. Sen and M. Young. (2001). “Equity Market in the Asia Pacific Region: A Comparison of the Orthogonalized and Generalized VAR Approaches", Global Finance Journal, 12: 1-33.

- Engle, R. F. and C. W. J. Granger. (1987). “Co-integration and Error Correction: Representation, Estimation and Testing", Econometrica, 55 (2): 251-276.

- Ezzat, H. (2012). "The Application of GARCH and EGARCH in Modeling the Volatility of Daily Stock Returns During Massive Shocks: The Empirical Case of Egypt", International Research Journal of Finance and Economics, 96:143-154. 
- Forbes, K. J. and R. Rigobon. (2002). “No Contagion, Only Interdependence: Measuring Stock Market Comovements", The Journal of Finance, 57 (5): 2223-2261.

- Girard, E.; M. Omran and T. Zaher. (2003). "On Risk and Return in MENA Capital Markets", International Journal of Business, 8 (3):285-314.

- Goetzmann, W.; L. Li and K. G. Rouwenhorst. (2005). "Long-term Global Market Correlations", Journal of Business, 78: 1-38.

- Granger, C. W. J. (1969). “Investigating Causal Relation by Econometric and Cross-sectional Method", Econometrica, 37: 424-438.

- Gregg, F. (2012). "why-global-diversification-still-makes-sense", Forbes Magazine, Available at: www.forbes.com/sites/greggfisher/2012/01/17/ (Accessed January 17).

- Guesmi, K. and F. Teulon. (2014). The Determinants of Regional Stock Market Integration in Middle East: A Conditional ICAPM Approach. IPAG Working Paper No. 214. IPAG Business School.

- Johansen, S. (1988). "Statistical Analysis of Cointegrated Vectors", Journal of Economic Dynamics and Control, 12: 231-254.

- Kazi, A.; K. Guesmi and O. Kaabia. (2013). “Does Shift Contagion Exist between OECD Stock Markets During the Financial Crisis?", Journal of Applied Business Research, 29: 469-484.

- Kim, S.; F. Moshirian and E. Wu. (2005). “Dynamic Stock Market Integration Driven by the European Monetary Union: An Empirical Analysis", Journal of Banking and Finance, 29: 2475-2502.

- Koop, G.; M. H. Pesaran and S. M. Potter. (1996). "Impulse Response Analysis in Nonlinear Multivariate Models", Journal of Econometrics, 74: 119-147.

- Lehkonen, H. (2015). "Stock Market Integration and the Global Financial Crisis", Review of Finance, 19 (5): 2039-2094.

- Li, K.; A. Sarkar and Z. Wang. (2003). “Diversification Benefits of Emerging Markets Subject to Portfolio Constraints", Journal of Empirical Finance, 10:57-80. http://dx.doi.org/10.1016/ S0927-5398(02)00027-0

- Longin, F. and B. Solnik. (1995). "Is the Correlation in International Equity Returns Constant?", Journal of International Money and Finance,14: 3-26.

- Markowitz, H. (1952). “Portfolio Selection”, Journal of Finance, 7: 77-91.

- Maghyereh, A. (2006). "Regional Integration of Stock Markets in MENA Countries", Journal of Emerging Market Finance, 5 (1), 59-94.

- Neaime, Simon. (2002). "Liberalization and Financial Integration of MENA Stock Markets", The ERF's $\boldsymbol{g}^{\text {th }}$ Annual Conference on Finance and Banking, United Arab Emirates.

- Parsva, P. and H. H. Lean. (2011). "The Analysis of Relationship between Stock Prices and Exchange Rates: Evidence from Six Middle Eastern Financial Markets", International Research Journal in Finance and Economics, 66: 157-171.

- Phengpis, C.and V.P.Apilado. (2003). Economic Interdependence and Common Stochastic Trends: A Comparative Analysis between EMU and Non-EMU Stock Markets. http://207.36.165.114/ Denver/Papers/Chanwit.pdf 
- Phillips, P. C. B. and P. Perron. (1988). “Testing for Unit Roots in Time Series Regression”, Biometrika, 75: 335-346.

- Phylaktis, K. and F. Ravazzolo. (2002). "Measuring Financial and Economic Integration with Equity Prices in Emerging Markets", Journal of International Money and Finance, 21 (6): 879-903.

- Phylaktis, K. and F. Ravazzolo. (2005). "Stock Prices and Exchange Rate Dynamics", Journal of International Money and Finance, 24 (7),1031-1053.

- Pukthuanthong, K. and R. Roll. (2009). “Global Market Integration: An Alternative Measure and Its Application", Journal of Financial Economics, 94: 214-232.

- Rim, H. and R. Setaputra. (2008). "Studies on the Financial Market Integration and Financial Efficiency: Evidences from Asian Markets", The Business Review, Cambridge, 10, 2.

- Solnik, B. H. (1974). "Why Not Diversifying Internationally Rather Than Domestically", Financial Analyst Journal, 51 (1): 89-94.

- Yu, J. S. and M. K. Hassan. (2008). "Global and Regional Integration of the Middle East and North African (MENA) Stock Markets", The Quarterly Review of Economics and Finance, 48 (3): 482-504.

- Watson, J. (1978). "A Study of Possible Gains From International Investment", Journal of Business Finance and Accounting, 5 (Summer): 195-206. 